\title{
Cytotoxic Constituents from the Stem Bark of Alvaradoa amorphoides
}

\author{
Carlos Quintal-Novelo, ${ }^{1}$ Luis W. Torres-Tapia, ${ }^{1}$ Rosa Moo-Puc, ${ }^{2}$ Sergio R. Peraza-Sanchez ${ }^{1, *}$ \\ ${ }^{1}$ Centro de Investigación Científica de Yucatán (CICY), Calle 43 No. 130, Col. Chuburná de Hidalgo, Mérida, Yucatán, México \\ 97200 \\ 2 Unidad de Investigación Médica, Centro Médico Ignacio García Téllez, Instituto Mexicano del Seguro Social (IMSS), Calle 41 \\ No. 439, Colonia Industrial, Mérida, Yucatán, México 97150 \\ * Corresponding author. E-mail: speraza@cicy.mx; Centro de Investigación Científica de Yucatán (CICY), Calle 43 No. 130 , \\ Col. Chuburná de Hidalgo, Mérida, Yucatán, México 97200. Fax: (999) 981-3900, Tel. (999) 942-8330, Ext. 264.
}

Received February $9^{\text {th }}, 2015$; Accepted September $11^{\text {th }}, 2015$

\begin{abstract}
The chemical study of Alvaradoa amorphoides led to the isolation of four major constituents: chrysophanol (1), $\beta$-sitosterol (2), atraric acid (3), and 17-octadecen-6-ynoic acid (4). All compounds were evaluated on in vitro cytotoxic and antiproliferative assays. Atraric acid and 17-octadecen-6-ynoic acid showed cytotoxic activity. Additionally, compound $\mathbf{4}$ exhibited cytotoxic activity showing a certain degree of selectivity against cancer cell lines.

Key words: Alvaradoa amorphoides, cytotoxic activity, antiproliferative activity, acetylenic compound.
\end{abstract}

\section{Introduction}

According to the World Health Organization, cancer is one of the most important causes of death in the world. This disease caused 7.6 million deaths in 2008 [1]. In addition, it has been described drug resistance in cancer cells; therefore, the discovery of new, more effective and selective antineoplasic agents is one of the most important challenges in this area [2,3]. According to the Food and Drug Administration (FDA), 40-45\% of all anticancer drugs approved from 1940 to 2006 corresponded to natural products or derived from them [4]. One of the most important sources for finding new anticancer drugs is the plant kingdom [5].

The genus Alvaradoa (Pricramniaceae) is a natural source of compounds with potential activity against cancer, having been possible to isolate metabolites with cytotoxic activity. Phytochemical analysis of $A$. haitiensis concluded in the isolation of 10 anthracenone $\mathrm{C}$-glycosides denominated alvaradoins E-N, and all compounds showed cytotoxic activity against KB cell line; furthermore, the compound alvaradoin E showed antileukemic activity on an in vivo model [6]. Regarding A. amorphoides, the stem bark is used in Mayan traditional medicine to treat skin disorders [7]. This species has only a few biological studies. Ankli et al. studied the dichloromethane and butanol leaf extracts, and they concluded that these extracts have cytotoxic activity against KB cell line [8]. Caamal-Fuentes et al. evaluated the methanol extract of the stem bark and this extract exhibited cytotoxicity against $\mathrm{KB}$ cells at $\mathrm{CC}_{50}=22.4 \mu \mathrm{gmL}^{-1}$ [9]. It is worth noticing that there are no reports of compounds
Resumen. De Alvaradoa amorphoides se aislaron cuatro compuestos: crisofanol (1), $\beta$-sitosterol (2), ácido atrárico (3) y el ácido 17-octadecen-6-inoico (4). Los compuestos fueron evaluados en los ensayos in vitro de actividad citotóxica y antiproliferativa. El ácido atrárico y el ácido 17-octadecen-6-inoico presentaron actividad citotóxica. Adicionalmente, el compuesto 4 mostró cierto grado de selectividad contra las líneas cancerígenas.

Palabras clave: Alvaradoa amorphoides, actividad citotóxica, actividad antiproliferativa, acetileno.

isolated from the stem bark of this plant. In view of the above, the aim of this work was to isolate, purify, and identify the cytotoxic constituents of the stem bark of $A$. amorphoides through its evaluation in five cancer cell lines: KB, Hep-2, HeLa, PC3, and MCF-7, and a normal cell line (Hek-293), using the MTT colorimetric method for cytotoxic activity and SRB for the antiproliferative bioassay.

\section{Results and discussion}

The crude methanol extract from the stem bark of A. amorphoides was fractionated by liquid-liquid separation, affording the hexane fraction; both, methanol extract and hexane fraction were evaluated against the $\mathrm{KB}$ cell line, showing $\mathrm{CC}_{50}=23.0$ and $38.0 \mu \mathrm{gmL}^{-1}$, respectively. The hexane fraction was subjected to successive chromatographic fractionation to afford four known compounds: chrysophanol (1), which is a common anthraquinone isolated from Alvaradoa species, included $A$. amorphoides [6,10,11]; $\beta$-sitosterol (2); atraric acid (3), which has previously been obtained from the stem bark of Pygeum africanum and being this the first report on its isolation from $A$. amorphoides [12]; and the acetylenic compound 17-octadecen-6-ynoic acid (4) [13,14]. The structures of compounds 1-4 were elucidated by IR, GC-MS, and NMR spectroscopic analyses and by comparison with the literature data (Figure 1). Compound 4 was originally isolated by Pearl et al. and it was identified by GC-MS by previously preparing its methyl derivative, the methyl 17-octadecen-6-ynoate [13]. Nevertheless, 
<smiles>Cc1cc(O)c2c(c1)C(=O)c1c(O)cccc1C2=O</smiles><smiles>CCC(CCC(C)C1CCC2C3CC=C4CC(O)CCC4(C)C3CCC12C)C(C)C</smiles><smiles>COC(=O)c1c(C)cc(O)c(C)c1O</smiles><smiles>C=CCCCCCCCCCC#CCCCCC(=O)O</smiles>

Figure 1. Compounds isolated from the stem bark of $A$. amorphoides.

this is the first time that compound $\mathbf{4}$ is isolated from the stem bark of $A$. amorphoides and the present work is contributing with the complete structural analysis of this molecule.

All compounds were evaluated against cancer cell lines (Tables 1 and 2). Compounds 3 and $\mathbf{4}$ showed cytotoxic activity (Table 1). The acetylenic-type compound (4) showed high selectivity against all tumor lines compared with the normal cell line. This high selectivity toward tumor cells is of great importance because the drugs used nowadays against cancer cause serious adverse effects. No reports exist about the biological activity of this enynoic acid. However, the 6-octadecynoic acid (tariric acid) inhibits the growth of fluconazole-susceptible and resistant Candida albicans strain [15]. Acetylenic compounds have a great potential as possible anticancer agents [16]. None of the compounds showed antiproliferative activity.

The current study supports the ethnomedical use of $A$. amorphoides as a remedy for the treatment of cancer-like symptoms. This is the first time that the acetylenic compound 17-octadecen-6-ynoic acid (4) is isolated from the stem bark, and according to the cytotoxic bioassay, 4 should be considered as a potential anticancer agent. Taking into account its cytotoxic activity and its high selectivity towards tumor cells, the 17-octadecen-6-ynoic acid may be a lead for further studies on its mechanism of action in cancer cells.

\section{Experimental}

Purification by column chromatography (CC) was performed using silica gel 60 (0.040-0.063 mm, Merck, Darmstadt, Germany) and pre-coated silica gel plates (Merck, Kieselgel $60 \mathrm{~F}_{254}$, $0.25 \mathrm{~mm}$ ) for preparative thin layer chromatography (PTLC). Gel permeation column chromatography was carried out using Sephadex LH-20 (Amersham Pharmacia Biotech AB, Sweden). Analytical TLC was performed on silica gel $60 \mathrm{~F}_{254}$ aluminum plates (E.M. Merck, $0.2 \mathrm{~mm}$ thickness). Detection of the components under UV/Vis light at 254 and $365 \mathrm{~nm}$ was performed on a Chromato-Vue ${ }^{\circledR}$ C-75 UV Viewing Cabinet. Visualization of components was carried out by using a solution of phospho-

Table 1. Cytotoxic activity of the compounds isolated from A. amorphoides.

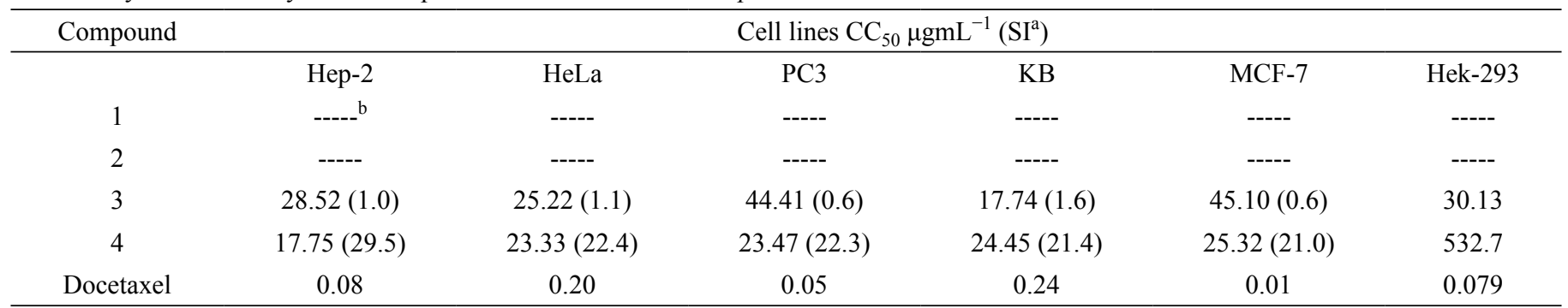

${ }^{\text {a }} \mathrm{SI}=$ Selectivity Index

b ---- $=\mathrm{CC}_{50}>100 \mu \mathrm{gmL}^{-1}$

Table 2. Antiproliferative activity of the compounds isolated from A. amorphoides.

\begin{tabular}{|c|c|c|c|c|c|c|}
\hline \multirow[t]{2}{*}{ Compound } & \multicolumn{6}{|c|}{ Cell lines $\mathrm{IC}_{50} \mu \mathrm{gmL}^{-1}\left(\mathrm{SI}^{\mathrm{a}}\right)$} \\
\hline & Hep-2 & $\mathrm{HeLa}$ & PC3 & KB & MCF-7 & Hek-293 \\
\hline 1 & ----- b & ----- & ----- & ----- & ----- & ----- \\
\hline 3 & $83.91(0.5)$ & $32.46(1.4)$ & $43.47(1.0)$ & $24(1.9)$ & ----- & 45.64 \\
\hline 4 & ----- & $98.41(3.6)$ & ----- & $69.91(5.1)$ & $51.65(6.9)$ & 359.3 \\
\hline
\end{tabular}

${ }^{\text {a }} \mathrm{SI}=$ selectivity Index

b ---- $=\mathrm{IC}_{50}>100 \mu \mathrm{gmL}^{-1}$ 
molybdic acid $(20 \mathrm{~g})$ and ceric sulfate $(2.5 \mathrm{~g})$ in $500 \mathrm{~mL}$ of sulfuric acid (5\%), followed by heating. IR spectra were taken on $\mathrm{KBr}$ discs on a Nicolet Protégé 460 spectrophotometer. NMR experiments were recorded on a Bruker Avance 400 Ultra Shield spectrometer in $\mathrm{CDCl}_{3}$. Gas chromatograms and low-resolution mass spectra were obtained on an Agilent Technologies GC-MS instrument (models 6890N and 5975B) using the following chromatographic conditions: split injection; $1 \mathrm{~mL}$ sample at $1 \%$ concentration; Ultra 1 column $(25 \mathrm{~m} \times 0.2 \mathrm{~mm}$ i.d.); flow rate $1.0 \mathrm{mLmin}^{-1}$ (helium as carrier gas); oven temperature program: $\mathrm{T} 1=180^{\circ} \mathrm{C}(3 \mathrm{~min}), \mathrm{T} 2=280^{\circ} \mathrm{C}(15 \mathrm{~min})$, gradient 10 ${ }^{\circ} \mathrm{C} / \mathrm{min}$; injector and detector (FID) temperature at $280{ }^{\circ} \mathrm{C}$. High-resolution mass spectra were obtained on a JEOL GCMate mass spectrometer. All solvents of technical grade employed for chromatographic separations were distilled prior to use.

\section{Plant Material}

Alvaradoa amorphoides Liebm. (Picramniaceae) was collected in Mococha, Yucatan, Mexico in October 2010. The plant material was identified and authenticated by taxonomists from the Unit of Natural Resources of the Scientific Research Center of Yucatan (CICY). A voucher specimen was deposited at CICY's U Najil Tikin Xiw herbarium (P.Simá 2972).

\section{Extraction and isolation}

The dried and powdered stem bark of A. amorphoides $(9.5 \mathrm{Kg})$ was extracted successively with methanol $(3 \times 15 \mathrm{~L})$ at room temperature for $72 \mathrm{~h}$. The methanol extract was concentrated under reduced pressure resulting in $1.2 \mathrm{Kg}$ of crude extract (12.6\%). An aliquot of the methanol extract (226.4 g) was suspended in a solution of methanol-water 1:1 $(1 \mathrm{~L})$ and it was partitioned with hexane to obtain the hexane fraction $(6.2 \mathrm{~g})$. The hexane fraction was subjected to an initial fractionation by vacuum liquid chromatography (VLC), eluting with n-hexane, n-hexane:ethyl acetate (EtOAc) gradient mixtures, EtOAc, EtOAc:methanol (1:1), and methanol $(\mathrm{MeOH})$, obtaining 21 fractions, which were pooled in 10 major fractions (A1-A10), according to their TLC profile. Fraction A8 (2.2 g) was passed through a column containing Sephadex LH-20, using $\mathrm{MeOH}$ for elution, yielding 38 fractions which were pooled in nine fractions (B1-B9) according to their TLC profile. Separation of B9 fraction $(953 \mathrm{mg})$ on silica gel $\mathrm{CC}$ with gradient mixtures of hexane:EtOAc was carried out to obtain compound $\mathbf{1}(13.6 \mathrm{mg})$ and compound $2(35.2 \mathrm{mg})$. Fraction B4 was loaded on a Sephadex $\mathrm{CC}$ and eluted with hexane: $\mathrm{CHCl}_{3}$ :methanol $(2: 1: 1, \mathrm{v} / \mathrm{v})$ to afford 21 fractions (C1-C21). Fraction C4 (245.8 mg) was subjected to flash CC, and eluted with hexane, hexane:EtOAc mixtures of increasing polarity, yielding compound 2 (49.0 $\mathrm{mg}$ ). Fractions C5 and C6 were combined $(292.6 \mathrm{mg}$ ), and then further purified by a silica gel column with hexane:acetone mixtures to give 76 fractions, which were pooled in 17 final fractions (D1-D17). Fraction D6 yielded compound 4 (13.5 $\mathrm{mg})$. Fraction B5 $(80 \mathrm{mg})$ was loaded on a silica gel CC and eluted with hexane, hexane:EtOAc mixtures of increasing po- larity, yielding 14 major fractions (E1-E14). From fraction E3 compound $1(5.3 \mathrm{mg})$ was obtained, fraction E8 yielded compound $3(6.3 \mathrm{mg})$, and fraction E10 yielded compound 2 (10.6 mg).

Chrysophanol (1) [17]: yellow crystals; $18.9 \mathrm{mg}$; IR (KBr) $v_{\max } 3400,1674,1625 \mathrm{~cm}^{-1} ;{ }^{1} \mathrm{H} \mathrm{NMR}\left(\mathrm{CDCl}_{3}, 400 \mathrm{MHz}\right) \delta$ $12.10(1 \mathrm{H}, \mathrm{s}, \mathrm{OH}-8), 11.99(1 \mathrm{H}, \mathrm{s}, \mathrm{OH}-1), 7.80(1 \mathrm{H}, \mathrm{dd}, J=1.1$, $7.4 \mathrm{~Hz}, \mathrm{H}-5), 7.66(1 \mathrm{H}, \mathrm{d}, J=8.2 \mathrm{~Hz}, \mathrm{H}-6), 7.63(1 \mathrm{H}, \mathrm{d}, J=1.0$ $\mathrm{Hz}, \mathrm{H}-4), 7.27(1 \mathrm{H}, \mathrm{dd}, J=1.1,8.4 \mathrm{~Hz}, \mathrm{H}-7), 7.08(1 \mathrm{H}, \mathrm{d}, J=$ $0.8 \mathrm{~Hz}, \mathrm{H}-2)$; EI-MS $(70 \mathrm{eV}) \mathrm{m} / z$ (rel. int. $)=254[\mathrm{M}]^{+}(100)$.

$\boldsymbol{\beta}$-Sitosterol (2). It was identified by comparison on TLC with an authentic sample and by means of GC-MS analysis.

Atraric acid (3): colorless needles; $6.3 \mathrm{mg}$; IR ( $\mathrm{KBr}) v_{\max }$ $3402,1625,1306,1274 \mathrm{~cm}^{-1} ;{ }^{1} \mathrm{H}$ NMR $\left(\mathrm{CDCl}_{3}, 400 \mathrm{MHz}\right) \delta$ $12.05(1 \mathrm{H}, \mathrm{s}, \mathrm{OH}-2), 6.21$ (1H, s, H-5), 3.92 (3H, s, OMe-1'), 2.45 (3H, s, Me-6), 2.10 (3H, s, Me-3); EI-MS (70 eV) $m / z$ (rel. int. $)=196[\mathrm{M}]^{+}(40), 164(60), 136(100)$.

17-Octadecen-6-ynoic acid (4): yellow oil (13.5 mg); IR (KBr) $v_{\max } 3075,2925,2841,2208,1707 \mathrm{~cm}^{-1} ;{ }^{1} \mathrm{H} \mathrm{NMR}\left(\mathrm{CDCl}_{3}, 400\right.$ $\mathrm{MHz}) \delta 1.26-1.37(12 \mathrm{H}, \mathrm{m}, \mathrm{H}-10-\mathrm{H}-15), 1.46(2 \mathrm{H}$, quintet, $J=7.6 \mathrm{~Hz}, \mathrm{H}-9), 1.53(2 \mathrm{H}$, quintet, $J=7.3 \mathrm{~Hz}, \mathrm{H}-4), 1.73(2 \mathrm{H}$, quintet, $J=7.7 \mathrm{~Hz}, \mathrm{H}-3), 2.03(2 \mathrm{H}, \mathrm{q}, J=7.5 \mathrm{~Hz}, \mathrm{H}-16), 2.12$ $(2 \mathrm{H}, \mathrm{m}, \mathrm{H}-8), 2.17(2 \mathrm{H}, \mathrm{m}, \mathrm{H}-5), 2.37$ (2H, t, $J=7.4 \mathrm{~Hz}, \mathrm{H}-2)$, $4.92(1 \mathrm{H}, \mathrm{ddt}, J=10.2,2.0,1.0 \mathrm{~Hz}, \mathrm{Ha}-18), 4.99(1 \mathrm{H}, \mathrm{dd}, J=$ $17.1,2.0 \mathrm{~Hz}, \mathrm{Hb}-18), 5.80(1 \mathrm{H}$, ddt, $J=16.9,10.2,6.6 \mathrm{~Hz}$, $\mathrm{H}-17) ;{ }^{13} \mathrm{C}$ NMR $\left(\mathrm{CDCl}_{3}, 100 \mathrm{MHz}\right) \delta 18.3$ (C-5), $18.8(\mathrm{C}-8)$, 23.8 (C-3), 28.3 (C-4), 28.8 (C-9), 28.8, 29.0, 29.0, 29.0, 29.3, 29.4, 33.3 (C-16), 33.7 (C-2), 79.2 (C-6), 80.7 (C-7), 114.0 (C18), 139.2 (C-17), 179.1 (C-1); HRCI-MS (direct probe) $\mathrm{m} / \mathrm{z}$ 278.2353 (calcd for $\mathrm{C}_{18} \mathrm{H}_{30} \mathrm{O}_{2}, m / z$ 278.2398).

\section{Cell culture}

The cytotoxic and antiproliferative activities of the extracts, fractions, and compounds were evaluated against six cell lines: laryngeal carcinoma (Hep-2, ATCC CCL-23), cervix adenocarcinoma (HeLa, ATCC-CCL-2), prostate adenocarcinoma (PC3, ATCC-CRL-1435), nasopharyngeal carcinoma (KB, ATCC-CCL-17), breast adenocarcinoma (MCF-7, ATCCHTB-22), and a human embryonic kidney cell line (Hek-293, ATCC-CRL-1573), from the American Type Culture Collection (ATCC). All were cultured in Dulbecco's Modified Eagle Medium (DMEM; Gibco) and supplemented with $10 \%$ heat-inactivated fetal bovine serum (FBS; Gibco), $100 \mathrm{UmL}^{-1}$ penicillin (InVitro), $100 \mu \mathrm{gmL}^{-1}$ streptomycin (InVitro), $2.5 \mu \mathrm{gmL}^{-1} \mathrm{am}$ photericin $\mathrm{B}$ (InVitro) in a $5 \% \mathrm{CO}_{2}$ humidified atmosphere at $37^{\circ} \mathrm{C}$. Dilution of stock solutions was made in culture medium yielding final extracts and compound concentrations of 3.125, $6.25,12.5,25$, and $50 \mu \mathrm{gmL}^{-1}$ with a final DMSO concentration of $0.01 \%$. This concentration of DMSO has no effect on the growth of cells. 


\section{Cytotoxicity and antiproliferative assays}

The cytotoxicity and antiproliferative assays were carried out according to a procedure described in the literature $[18,19]$. We used the MTT method for cytotoxicity assay and SRB for the antiproliferative assay. The experiments were performed in triplicate and the concentrations that killed $50 \%$ of the cells $\left(\mathrm{CC}_{50}\right)$ or inhibited $50 \%$ of the cells $\left(\mathrm{IC}_{50}\right)$ were calculated by GraphPad Prism 4 software.

\section{Acknowledgments}

This research was financed by CONACYT (Project No. 156755). Carlos Quintal-Novelo is grateful to CONACYT for the scholarship No. 211980. The authors wish to thank Paulino Sima-Polanco, from the Unit of Natural Resources (CICY), for the collection and identification of plant material. The authors are grateful to Dr. Andrew James for English review of the paper.

\section{References}

1. Jemal A., Bray F., Center M. M., Ferlay J., Ward E., Forman D. CA. Cancer J. Clin. 2011, 61, 69-90.

2. Gottesman, M. Annu. Rev. Med. 2002, 53, 615-627.

3. Thomas, H.; Coley, H. M. Cancer Control 2003, 10, 159-165.

4. Newman, D. J.; Cragg, G. M. J. Nat. Prod. 2007, 70, 461-477.

5. Cragg, G. M.; Newman, D. J. J. Ethnopharmacol.2005, 100, 72-79.
6. Phifer, S. S.; Lee, D.; Seo, E. K.; Kim, N. C.; Graf, T. N.; Kroll, D. J.; Navarro, H. A.; Izydore, R. A.; Jimenez, F.; García, R.; Rose, W. C.; Fairchild, C. R.; Wild, R.; Soejarto, D. D.; Farnsworth, N. R.; Kinghorn, A. D.; Oberlies, N. H.; Wall, M. E.; Wani, M. C. J. Nat. Prod. 2007, 70, 954-961.

7. Osadao, R., El Libro del Judío o Medicina Doméstica, Descripción de las Virtudes de las Yerbas Medicinales de Yucatán. Additional notes of Dr. Andrew Heath de Zapata, Mérida, Yucatán, México, 1834, 20-255.

8. Ankli, A.; Heinrich, M.; Bork, P.; Wolfram, L.; Bauerfeind, P.; Brun, R.; Schmid, C.; Weiss, C.; Bruggisser, R.; Gertsch, J.; Wasescha, M.; Sticher, O. J. Ethnopharmacol. 2002, 79, 43-52.

9. Caamal-Fuentes, E.; Torres-Tapia, L. W.; Sima-Polanco, P.; Peraza-Sanchez, S. R.; Moo-Puc, R. J. Ethnopharmacol. 2011, 135, 719-734.

10. Soto de Villatoro, B.; Giral Gonzalez, F.; Polonsky, J.; Baskevitch-Varon, Z. Phytochemistry 1974, 13, 2018-2019.

11. Harding, W.; Henry, G.; Lewis, P.; Jacobs, H.; McLean, S.; Reynolds, W. J. Nat. Prod. 1999, 62, 98-101.

12. Schleich, S.; Papaioannou, M.; Baniahmad, A.; Matusch, R. Planta Med. 2006, 72, 547-551.

13. Pearl, M. B.; Kleiman, R.; Earle, F. R. Lipids. 1973, 8, 627-630.

14. Minto, R. E.; Blacklock, B. J. Prog. Lipid Res. 2008, 47, 233-306.

15. Li, X. C.; Jacob, M. R.; ElSohly, H. N.; Nagle, D. G.; Smillie, T. J.; Walker, L. A.; Clark, A. M. J. Nat. Prod. 2003, 66, 1132-1135.

16. Dembitsky, V. M. Lipids 2006, 41, 883-924.

17. García-Sosa, K.; Villareal-Álvarez, N.; Lübben, P.; Peña-Rodriguez, L. M. J. Mex. Chem. Soc. 2006, 50, 76-78.

18. Denizot, F.; Lang, R. J. Immunol. Methods 1986, 89, 271-277.

19. Skehan, P.; Storeng, R.; Scudiero, D.; Monks, A.; McMahon, J.; Vistica, D.; Warren, J. T.; Bokesch, H.; Kenney, S.; Boyd, M. R. J. Natl. Cancer Inst. 1990, 82, 1107-1112. 